\title{
La narrativa de Roberto Bolaño a escena: 2666
}

\author{
Roberto Bolaño's Narrative on Stage: 2666
}

\author{
Ana Prieto Nadal \\ SELITEN@T (UNED) \\ apriet22@gmail.com
}

\section{RESUMEN}

En este artículo nos proponemos abordar el análisis del espectáculo 2666, dramatización de la novela homónima de Roberto Bolaño, adaptada por Pablo Ley y Àlex Rigola y dirigida por este último. El montaje se hace eco de la complejidad, fragmentariedad y multiperspectivismo de la novela, evidenciando una decidida apuesta por la intermedialidad al tiempo que una firme voluntad de mantener la tensión narrativa del texto original y el lirismo de la palabra de Bolaño.

Palabras Clave: 2666; Roberto Bolaño; Àlex Rigola; dramatización; puesta en escena.

\section{ABSTRACT}

In this paper we set out to analyze the play 2666 , a dramatization of the homonymous Roberto Bolaño's novel, adapted by Pablo Ley and Alex Rigola and directed by this last one. The staging keeps the complexity, fragmentariness and multiperspectivism of the novel, investing in intermediality as well as respecting faithfully the narrative tension of the original and the lyricism of Bolaño's word.

Key words: 2666; Roberto Bolaño; Àlex Rigola; Dramatization; Staging.

\section{De la narrativa Al teatro. Puntos De Fuga}

A propósito de la gran novela póstuma de Roberto Bolaño, señala Jorge Volpi que «Hay quien mira 2666 como quien se asoma a un abismo o a un espejo empañado [...] quien encuentra en sus páginas la mayor decantación del estilo y las obsesiones de Bolaño»(Volpi, 2008: 205). 2666 nos confronta a una tierra feroz, un desierto insaciable que es también un espejo y en el que se abren, como fauces devoradoras, los puntos equívocos de la realidad donde empieza la pesadilla. Su textualidad es digresiva y expansiva: el hilo conductor se borra y el argumento se suspende al punto casi de olvidarse, por la multiplicación de personajes y anécdotas; temas como la escritura, el arte, la posteridad o la locura son abordados desde múltiples peripecias y perspecti-

Copyright: (C) 2016 CSIC. Este es un artículo de acceso abierto distribuido bajo los términos de una licencia de uso y distribución Creative Commons Attribution (CC-by) España 3.0. 
vas. Bolaño yuxtapone distintos relatos, haciéndolos intersectar en ocasiones; los despliega como cajas chinas, muñecas rusas o cuentos milesios. A la diseminación de gérmenes narrativos, cabe añadir asimismo las contaminaciones con otros géneros. Celina Manzoni (2002: 42) habla de «incorporación desprejuiciada de códigos no literarios: los de la música, las artes plásticas, el cine, aun en sus variantes menos ortodoxas: el gore, la snuff movie, la pornografía; la velocidad del video clip, el enigma del video game».

2666 fue adaptada para la escena por Pablo Ley y Àlex Rigola, en un espectáculo dirigido por este último. El 27 de junio de 2007 se estrenó en el Teatre Lliure de Barcelona, en el marco del Grec Festival de Barcelona. Obtuvo, entre otros muchos galardones, el Premio de la Crítica 2007 al Mejor Espectáculo Teatral, Mejor Dramaturgia y Mejor Escenografía, y el Premio Max 2009 al Mejor Espectáculo Teatral y a la Mejor Escenografía. El 3 de abril de 2014 se estrenó la versión alemana de 2666 en la Schaubühne de Berlín, también bajo la dirección de Àlex Rigola.

Se ha comparado la dirección de 2666 con montajes míticos de Robert Lépage —Los siete afluentes del río Ota (1995) - y de Krystian Lupa — Los hermanos Karamazov (1990) y Extinción (2001)—․․ Como señala Pablo Ley (2007: s.p.), Rigola bebe de las diversas corrientes de vanguardia del siglo XX y tiene una visión comprometida con el teatro progresista europeo de las últimas décadas. Empezó su carrera como director a finales de los años noventa, y tuvo a inicios del siglo XXI una trayectoria ascendente e imparable, jalonada por versiones actualizadas de obras de Shakespeare - Titus Andrònic (2000), Julio César (2002), European House (Prólogo a un Hamlet sin palabras) (2005), Ricardo 3. ${ }^{\circ}$ (2005) - y montajes de piezas que han sido claves en la renovación de la escena contemporánea, como Woyzek (2001) de Georg Büchner, Ubú Rey (2002) de Alfred Jarry, Glengarry Glen Ross (2003) de David Mamet, Santa Juana de los Mataderos (2004) de Bertold Brecht y La noche justo antes de los bosques (2006) de Bernard-Marie Koltès, entre otras muchas. Ya había hecho el ejercicio de dramatizar una novela con El proceso de Kafka —Kafka: El Procés (1997)_, pero la adaptación de 2666 constituye una empresa gigantesca y sin precedentes. Ésta es la primera vez pero no la última que Rigola lleva a escena un texto de de Bolaño: en 2013 estrena la versión teatral del relato «El policía de las ratas», en un formato íntimo y minimalista ${ }^{2}$, muy distinto de 2666. Próximamente, en mayo de 2015, estre-

${ }^{1}$ Vid. Ordóñez, Marcos (2007). «Cinco horas con Bolaño», El País. 14 de julio, p. 20; Fondevila, Santiago (2007). «Àlex Rigola convierte el 2666 de Roberto Bolaño en una obra teatral de cinco horas», La Vanguardia. 26 de junio, p. 40.

${ }^{2}$ En nuestro artículo «El policía de las ratas a escena» (Prieto Nadal, 2014) analizamos la puesta en escena de El policía de las ratas, poniéndola en relación con el relato homónimo de Bolaño y asimismo con otro de Franz Kafka, «Josefina la Cantora o El pueblo de los ratones», que le sirvió de punto de partida al escritor chileno. 
nará su particular lectura escénica de otra novela, Incerta glòria de Joan Sales. El propio Àlex Rigola confiesa que le gusta visualizar historias que otros han escrito, y a partir de ellas realizar retratos de la sociedad que permitan al espectador sacar sus propias conclusiones: «No doy soluciones, porque no creo que ésa sea mi función, sino poner a una parte de la sociedad en el microscopio para observarla. Lo demás es producir cambios en la respiración del espectador, emocionarlo» ${ }^{3}$.

A propósito de la adaptación de novelas o relatos al medio teatral, José Sanchis Sinisterra (2003: 11) habla de un territorio fronterizo en el que la diferenciación entre lo épico y lo dramático empieza a oscilar, permitiendo una ampliación de los horizontes de la teatralidad y abarcando gran variedad de matices, desde la epicidad pura del actor-rapsoda hasta la dramaticidad pura. Rigola y Ley optan en general por una solución intermedia, apostando en muchas ocasiones por los narradores múltiples, en que varios personajes se turnan a la hora de relatar, alternando la función épica y la representativa y abriéndose a una polifonía de la voz narrativa. Rigola declara su voluntad de serle fiel al verbo de Bolaño, a su empuje narrativo y a su aliento poético — «una de las cosas más importantes de esta historia es, evidentemente, la palabra. Y el hecho de la narración obliga a buscar [...] diferentes formas de narración en un mismo espectáculo» ${ }^{4}$ - , sin renunciar a la explotación de los resortes escénicos ni a la experimentación formal.

En cuanto a la estructura en pentalogía del espectáculo, fiel reflejo de la configuración de la novela, Pablo Ley (2007: s.p.) explica que su voluntad fue la de enfrentarse a cinco novelas con cinco argumentos bien diferenciados, cinco esquemas de personajes completamente distintos y cinco temas perfectamente definidos, priorizando los hechos que constituyen puntos de conexión dentro de la propia novela y los personajes que transitan de una parte a otra. Ley señala también que hay dos polos — dos extremos de una misma pulsión mental - que tensan el eje temático de la novela: la figura de Benno von Archimboldi como enigma de la creación y los asesinatos de Santa Teresa como enigma de la destrucción.

A nivel de escenografía - a cargo de Max Glaenzel y Estel Cristià-, se definen cinco espacios de los infinitos que en la novela se mencionan o dibujan. En cada una de las partes, un espacio escénico — sala de conferencias, patio con verja, cubo-ring-televisor, desierto, espacio vacío con pantalla y cinta de correr - configura la imagen, arbitraria, de un paisaje contenedor que engloba todos los demás espacios evocados y referenciados.

\footnotetext{
${ }^{3}$ Larios Ruiz, Shaday (2008). «Àlex Rigola: "Busco que la gente se cuestione lo que ve”», La Tempestad. 58, pp. 10-11.

${ }^{4}$ Entrevista realizada por María Zaragoza el 27 de febrero de 2006 en el Cafè de l'Òpera de Barcelona e incluida en el dossier de prensa: <http://www.teatrelliure.com/webantiga/1213/ documents/ddt/ddt12/DDT12.02.2666.pdf> [ref. de 12/7/16].
} 
Al inicio del espectáculo se proyectan las célebres palabras que aparecen en la novela Amuleto, en alusión intertextual a la cifra que da título a la obra, al «cementerio de 2666, un cementerio olvidado debajo de un párpado muerto o nonato, las acuosidades desapasionadas de un ojo que por querer olvidar algo ha terminado por olvidarlo todo» (Bolaño, 1999: 77). A propósito de esta cifra señala Peter Elmore (2008: 261) que «El año 2000 y la cifra del Anticristo se funden en el título, que indica el encuentro - inestable, extraño- de la crónica de lo contemporáneo con el registro visionario». Para José Ramón López García (2008: 207), el cementerio aludido en Amuleto constituye la «metáfora espacio-temporal que delimita las coordenadas por las que después transcurre asimismo la propuesta de Rigola y Ley».

\section{LA PARTE DE LOS CRÍTICOS}

La sobriedad escenográfica y lumínica de la primera parte del montaje remite al espacio vacío de Peter Brook. Se proyectan al fondo las cuatro cifras que dan título a la obra, y de la oscuridad emergen una pizarra acrílica blanca, una mesa de conferencias con cuatro micrófonos y cuatro botellas de agua, tres sillas propias de un entorno académico y una silla de ruedas.

El primer personaje que entra en escena es Manuel Espinoza —interpretado por Julio Manrique-: revisa los objetos que hay en la mesa, coloca bien las sillas y se dirige a la pizarra, donde escribe el nombre de Benno von Archimboldi. Entran Piero Morini - interpretado por Andreu Benito- y JeanClaude Pelletier - interpretado por Joan Carreras - y se sitúan delante de la mesa. Se presentan unos a otros como críticos y traductores, y sobre todo como los máximos especialistas de sus respectivos países - España, Italia y Francia - en la obra del enigmático autor alemán Benno von Archimboldi. Espinoza va anotando los datos más relevantes en la pizarra. Cuando Pelletier explica que a Morini le detectaron una esclerosis múltiple, el actor Andreu Benito se dirige hacia la silla de ruedas y se sienta en ella. Entra la inglesa Liz Norton -interpretada por Chantal Aimée-, también especialista en la obra de Archimboldi, y explica cómo un congreso de literatura alemana contemporánea celebrado en 1994 en Bremen marcó el inicio de su amistad, al unirse los cuatro en una encendida defensa de Archimboldi.

A partir de aquí, los cuatro críticos, casi como si fueran la misma persona, se turnan para referir al público su andadura en común y su creciente amistad, traducida en constantes llamadas telefónicas y varios encuentros en distintos puntos de la geografía europea; Pelletier y Espinoza se levantan de vez en cuando para apuntar algún dato en la pizarra. Toma cuerpo el misterio de la biografía de Archimboldi, así como el laberinto de pasiones cruzadas entre Norton y los demás críticos. También se relata la visita a la editora de Archimboldi, la señora Bubis, «una mujer que no se aferraba a los bordes del 
abismo sino que caía al abismo con curiosidad y elegancia» (Bolaño, 2007: s.p.); cuando la evocan, comparece fugazmente, en el lateral derecho del escenario, la señora Bubis, una mujer elegante y sofisticada que interpreta Alícia Pérez. Cuando esta breve visión desaparece, los críticos siguen su narración a cuatro voces.

Pelletier y Espinoza se relevan alternativamente en las funciones de narrador para hablar de su triángulo amoroso con Norton, que se desarrolla en diversos escenarios europeos. Especial importancia tiene el encuentro a tres bandas en Londres, donde Pelletier y Espinoza se presentaron por sorpresa un fin de semana: «Norton nos miró como si fuéramos dos amigos muertos hace mucho» (Bolaño, 2007: s.p.). El reencuentro, con cena incluida, lo explican entre los tres, en un primer momento riéndose y después repentinamente serios y sobrecogidos, para abordar la narración del episodio con un taxista paquistaní que les recriminó por sus actitudes sexuales y al que golpearon hasta causarle una conmoción cerebral y graves lesiones en todo el cuerpo. Después se refiere una anécdota posterior, un viaje a Suiza en que Pelletier, Espinoza y Morini fueron a visitar al pintor Edwin Johns al manicomio de Montreaux, en el que éste había sido encerrado por incluir en su último autorretrato su mano derecha momificada; Julio Manrique asume la voz del pintor mutilado y susurra al oído a Morini el motivo por el que se cortó el brazo.

A continuación los tres hombres se turnan para contar $-\mathrm{y}$ ahora Norton es quien anota nombres en la pizarra- cómo supieron del posible paradero del ya octogenario Archimboldi, una ciudad llamada Santa Teresa, en la frontera de México con los Estados Unidos. Morini, en silla de ruedas, se retira a un lado para después levantarse y salir del escenario. Pelletier, Espinoza y Norton explican su decisión de ir a la ciudad de Santa Teresa. Cuando el actor Andreu Benito reaparezca en escena ya no será como Morini sino como Amalfitano — un melancólico profesor de filosofía, experto en la obra de Archimboldi-; él se encargará de anotar los datos en la pizarra.

Ya en Santa Teresa, los críticos — cuentan- deambulan por la ciudad, y, a medida que describen las calles, las gentes, los horizontes y las bandadas de buitres vigilantes, se proyectan, sobre la pizarra emborronada de nombres, imágenes de Ciudad Juárez. Así, en palabras de Begoña Barrena ${ }^{5}$, las «letras que prefiguran la densidad de la obra [...] se funden eficazmente con las imágenes de Ciudad Juárez rodadas por Rigola, una transición casi poética que nos lleva al centro físico de la obra». Los críticos, desubicados en esa zona fronteriza que es Santa Teresa, sufren una involución; en su diaria revisión de los periódicos, en busca del nombre de Archimboldi, pasan por alto lo más grave que sucede en Santa Teresa: los asesinatos de cientos de mujeres. Vemos cómo progresivamente, y ello será confirmado por el resto de personajes de la obra,

\footnotetext{
${ }^{5}$ Barrena, Begoña (2007). «Valiente traslación», El País. 29 de junio, p. 58.
} 
en sus distintas partes, «el desarraigo existencial de todos los protagonistas confluye en la transfiguración de Ciudad Juárez [...] ya no se distingue quiénes son los vivos y quiénes los muertos, puesto que los primeros aparecen más borrosos y sin vida que los segundos» (Bolognese, 2009: 100). En el caso de los críticos, acostumbrados a desplazarse libremente por el mundo, se confirma aquella paradoja y contradicción que señalara el antropólogo Marc Augé (1996: 104-105) a propósito de nuestra época, que él denomina sobremodernidad: a pesar de que el individuo tiene cada vez más fácil el acceso a lugares, personas e imágenes, también progresivamente se va replegando sobre sí mismo, deviniendo más un testigo que un actor de la vida contemporánea.

Huyendo del pernicioso influjo de Santa Teresa, Norton decide ir a Italia para reunirse con Morini, mientras que Pelletier y Espinoza seguirán perdiendo su tiempo, fuerzas e identidad en Santa Teresa, aun a sabiendas de que jamás encontrarán al escritor — «Archimboldi está aquí, y nosotros estamos aquí, y esto es lo más cerca que jamás estaremos de él» (Bolaño, 2007: s.p.)—. Norton, sentada en la silla de ruedas y, por lo tanto, ya en Italia, habla de su amor por Morini: «No sé cuánto tiempo vamos a durar juntos. Ni a Morini (creo) ni a mí nos importa. Nos queremos y somos felices. [...] ¿Cómo pude tardar tanto en darme cuenta de que yo lo quería?» (Bolaño, 2007: s.p.). Todos los personajes recogen sus bártulos y salen de escena. Se hace la oscuridad y queda sólo visible la pizarra con los datos de la búsqueda de Archimboldi.

Esta primera parte, que dura cerca de 50 minutos, se desarrolla enteramente en el proscenio. El contexto creado permite quintaesenciar el tipo de relación mantenida por los críticos, que puede muy bien simbolizarse en la sala de conferencias, emblema del mundo académico, si bien el público nunca llega a ser ficcionalizado como auditorio de una conferencia. Tampoco la actuación de los personajes — representantes cuasiparódicos de la universidad europea, con sus ritos culturales y su academicismo estéril- discurre como un acto académico. Se renuncia a contar en el aquí y el ahora, y se recurre a la interacción verbal y gestual entre los actores. Esta modalidad de los narradores múltiples que encarnan a personajes del relato permite transitar de la narración a secuencias dramáticas, pequeñas estructuras de puesta en escena, con silencios, interpelaciones, diálogos y miradas que permiten revivir lo contado. Esta primera parte, la más austera de las cinco, es trabajada desde la dirección como una conferencia en que los ponentes son los cuatro protagonistas de esta historia: se va imponiendo, por encima de la distancia y el protocolo iniciales, una progresiva implicación de los personajes en los hechos que narran. Dos de ellos, Espinoza y Pelletier, acaban difuminados, perdidos, engullidos por una tierra fronteriza por la que nadie puede transitar indemnemente. Se prefigura así la ciudad infierno que condiciona las acciones y la psique de los personajes de las tres siguientes partes. 


\section{LA PARTE DE AMALFITANO}

La acotación inicial indica que Amalfitano - Andreu Benito - tiene en las manos un libro muy extraño, que no recuerda haber comprado. Una gran empalizada abarca todo el ancho del escenario. A la derecha, una mesa y sillas de plástico. Domina una luz anaranjada, cálida y uniforme. Mientras lo hojea, Amalfitano enuncia el título del libro: Testamento geométrico, de Rafael Dieste. Rosa Amalfitano - interpretada por Cristina Brondo- recoge la ropa del tendedero que hay a la izquierda. El profesor cuelga el libro en el tendedero para ver cómo resiste a la lluvia y el viento, haciéndose eco de la célebre idea de Marcel Duchamp de dejar un libro de geometría a la intemperie para ver si aprende cuatro cosas de la vida real.

Cuando Rosa sale de escena, Amalfitano se pregunta por qué se fue a vivir allí y trajo a su hija a esa ciudad maldita. El profesor - a la vez personaje e instancia narrativa - cuenta que, cuando vivían en España, su mujer Lola lo abandonó para ir a conocer a su poeta favorito al manicomio de Mondragón — clara alusión, corroborada por otras posteriores, al poeta Leopoldo Panero-. Amalfitano refiere cómo Lola lo besó en las mejillas y se marchó sin despedirse de su hija de dos años; también que al cabo de una semana le mandó una carta desde Pamplona en la que evocaba la noche en que hizo el amor con el poeta, en el piso que éste compartía con un conocido filósofo; después iría al manicomio de Mondragón, donde estaba internado, con la intención de irse a vivir con él. Lola -interpretada por Alícia Pérez- aparece sentada en una silla de plástico; se trata de un recuerdo que cobra vida y habla.

Lola y Amalfitano se turnan para contar las vivencias de ella en España y después en Francia. Así, se narra cómo Lola hizo el amor entre las lápidas de un cementerio con un conductor desconocido que la había recogido de vuelta del manicomio - el cementerio de Santa Teresa parece prefigurado ya en esta segunda parte, en el cementerio de Mondragón-, y cómo después se fue a vivir a París y tuvo otro hijo. Lola apareció años después en la casa de Amalfitano, en Sant Cugat, y le dijo que estaba enferma de sida y que había querido ver a Rosa por última vez. Lola se desliza hacia el lateral y sale. Suenan acordes de la banda sonora de Paris, Texas (Wim Wenders, 1984).

Después Amalfitano cuenta que decidió dejar España y se fue a vivir a Santa Teresa, una ciudad que huele a muerto. Entran y se sientan el Decano Guerra, de la Facultad de Filosofía y Letras -interpretado por Manuel Carlos Lillo-, y su hijo, el Joven Guerra -interpretado por Ferran Carvajal—. Rosa Amalfitano les sirve unas copas, pero el Joven Guerra saca algo más fuerte, mezcal Los Suicidas. Padre e hijo se quejan de la situación de la ciudad, a la que llega cada vez más gente para trabajar en las maquiladoras, «las fábricas que los yanquis han instalado en nuestra parte de la frontera. Las ventajas de una mano de obra muy barata» (Bolaño, 2007: s.p.). Dice el Joven Guerra que lo que él haría sería quemar unas cuantas maquilas, y sacar el ejército a las carreteras 
para evitar que sigan llegando más muertos de hambre. Expresa así su profundo desprecio por lo que el sociólogo polaco Zygmunt Bauman (2005: 18) ha dado en llamar seres humanos residuales, excedentes y superfluos o supernumerarios, que la globalización no regulada y políticamente incontrolada ha condenado a la superfluidad y ha confinado a una zona fronteriza en el espacio de flujos planetario; estos náufragos o víctimas colaterales del progreso exhalan —añade Bauman (2005: 78) — «ese leve olor a vertedero de basuras que, con sus muchos disfraces, ronda las noches de las víctimas potenciales de la creciente vulnerabilidad». Después el Joven Guerra saca una pistola, apunta primero a Amalfitano y después a su propio padre, mientras asegura que «La gente es cobarde hasta el último aliento» (Bolaño, 2007: s.p.).

Amalfitano, solo en el escenario, mantiene un diálogo con la voz de su padre, y la escena se tiñe de azul. Le dice que todo nos traiciona, hasta la ética, el amor y el arte. En la alusión a Edwin Johns — «Hablo de un taller con las luces apagadas donde el nervio de la voluntad se desprende del resto del cuerpo [...]. ¿Te has preguntado si una mano es una mano?» (Bolaño, 2007: s.p.) - hay un punto de conexión con la primera parte, como en el hecho de que los críticos coincidieran con el Joven Guerra una noche que salieron de bares con Amalfitano. La voz del padre habla de los asesinatos de mujeres en Sonora: «Mala pinta. Tienes que tener cuidado, camarada, me parece que aquí las cosas están al rojo vivo» (Bolaño, 2007: s.p.).

El Decano se levanta y mira el libro tendido. El Joven Guerra le cuenta a Amalfitano el secreto de sus noches salvajes en tugurios inimaginables. El actor Ferran Carvajal habla de pie y acompaña sus palabras con movimientos levemente coreografiados; luego se calla y ejecuta unos pasos de baile. Amalfitano, nuevamente solo en escena, recupera la voz narrativa y cuenta que la misma noche en que sucedió todo aquello, la escena que acaba de ser representada, soñó que veía aparecer en un patio de mármol rosa al último filósofo comunista del siglo XX, que cantaba una canción en ruso - una canción acerca del triste destino de los hombres - mientras su corpacho se desplazaba haciendo eses; descubrió con estupor que se trataba de Boris Yeltsin, que lo miraba como si fuera Amalfitano quien acabara de irrumpir en su sueño. Se agita la sombra de unos brazos al otro lado de la verja; cae una estaca de la valla y asoma el actor Manuel Carlos Lillo con una máscara de Yeltsin: «Camarada, te voy a explicar cuál es la tercera pata de la mesa humana. La vida es demanda y oferta [...] pero así no se puede vivir. Es necesaria una tercera pata para que la mesa no se desplome en los basurales de la historia, [...] en los basurales del vacío»; la ecuación que propone consiste en sumarle la magia a la ley de la oferta y la demanda: «iY qué es magia? Magia es épica y también es sexo y bruma dionisiaca y juego» (Bolaño, 2007: s.p.). Aquí se retoman, parafraseadas, unas palabras de la primera parte, asimismo escritas en la pizarra blanca, cuando Norton hablaba de cómo Pelletier, en su defensa de Archimboldi en Bremen, se entregó con entusiasmo a la «visión dionisiaca, festiva, de exégesis de último carnaval» (Bolaño, 2007: s.p.). Yeltsin se va 
y se oye de nuevo la voz del padre de Amalfitano. Cae un telón sólido como una puerta metálica que cerrara herméticamente el escenario, mientras resuenan las últimas palabras del padre de Amalfitano: las cosas están al rojo vivo.

En la puesta en escena de Rigola, los personajes refieren la historia y la dramatizan. Amalfitano asume un relato retrospectivo en primera persona, pero también acciones físicas propias de un personaje en situación. No se crea un marco o contexto dramático que justifique que los personajes se cuenten una historia, sino que narración y acción se yuxtaponen en un escenario evocador del espacio desde donde habla Amalfitano, su patio con verja. Por otra parte, como señala Aarón Rodríguez Serrano (2010: s.p.), esta voz en off distorsionada que asume el fantasma del padre de Amalfitano revela hasta qué punto los muertos de 2666 utilizan el lenguaje para expresarse — lo mismo ocurría con Lola, la ex esposa de Amalfitano- y devienen así imagen o símbolo, «placebo tranquilizante ante la idea de la muerte».

La segunda parte de la novela 2666 es más onírica que la primera, con mayores dosis de irrealidad — se escenifican recuerdos e incluso sueños o alucinaciones-, y nos introduce en la atmósfera enrarecida y malsana de Santa Teresa, trasunto de Ciudad Juárez. Es el inicio del descenso a los infiernos, que anticipa que lo peor está por venir, y tiene una traducción escénica que va desde las referencias intelectuales del principio a una prefiguración de la insondable violencia que se cierne sobre ese paisaje. Barrena ${ }^{6}$ nos hace reparar en el formato cinemascope que adquiere el escenario, muy en consonancia con los acordes de Canción mixteca, de la banda sonora de Ry Cooder para París, Texas, que confieren a la pieza un aire de western contemporáneo. López García (2008: 213) señala asimismo la película de Wenders como «terreno de confluencias temáticas (la soledad del individuo, el viaje a ninguna parte, la figura del padre), visuales (el desierto, el formato en cinemascope del escenario) o sonoras». También David Lynch está en la base de referencias fílmicas de Rigola; así, Marcos Ordóñez ${ }^{7}$ califica esta parte de «alucinación pintada con los colores hiperrealistas de Lynch». La cerca de madera que recorre el escenario remite a la noción de frontera - entre países, entre culturas, entre estados de conciencia, entre niveles de percepción-. En ese lugar de paso, Amalfitano es visitado por todo tipo de personajes. Realidad y ficción, sueño y vigilia se confunden. El resultado está cerca de lo surreal.

\section{LA PARTE DE FATE}

Si en la parte anterior se aprovechaba todo el ancho del escenario, ocupado por una enorme valla - símbolo del estado de excepción y de frontera de

\footnotetext{
${ }^{6}$ Barrena, Begoña... Vid. supra nota 5.

${ }^{7}$ Ordóñez, Marcos... Vid. supra nota 1.
} 
Santa Teresa-, la tercera, que entronca con la novela y el cine negros, se desarrolla en un espacio muy reducido, un cubo de 3 por 1,5 metros en el centro del escenario. Al principio hay sólo una figura sentada, un sparring interpretado por Joan Carreras. Por encima del fondo verde se proyectan las imágenes de Óscar Fate —interpretado por Jorge Manrique- y Barry Seaman - Pere Arquillué - sentados en un bar con las caras tiznadas de negro. La acotación de Ley y Rigola (Bolaño, 2007: s.p.) dice que entre ambos personajes hay una grabadora, y que se oye un rap de fondo, pero en la puesta en escena la música que se oye es Mr. Tambourine Man de Bob Dylan, y Fate toma notas en un cuaderno sobre el tema de los Panteras Negras. El periodista anuncia que debe irse, pues le espera un largo viaje a Santa Teresa, para ir a cubrir un combate de boxeo. Seaman menciona los crímenes y le advierte que es difícil conducir por el desierto: «Los atardeceres en el desierto parece que no vayan a acabar nunca, hasta que de pronto todo acaba, sin ningún aviso. Es como si alguien simplemente desconectara la luz» (Bolaño, 2007: s.p.). Se prefigura aquí el desierto como «un lugar inhóspito por definición, una tierra hostil al hombre y raramente visitada por él», tal como lo definiera Bauman (2009: 179), y, más concretamente, el desierto de Sonora como «emblema de la indefinición, de la nada, del viaje y de la búsqueda inútil» (Bolognese, 2009: 95).

Mientras tiene lugar la proyección en la parte de arriba del cubículo, el sparring situado dentro se levanta y sale; entra Rosita Méndez —interpretada por Alba Pujol, con vestido rojo ajustado y peluca rubia-, que se contonea suavemente con una botella de cerveza en la mano. Con el cese de la proyección se pasa de Estados Unidos a México. Entra Charly Cruz - Víctor Pi, con una camiseta de Star Wars bajo la camisa hawaiana-, de quien se nos dice que regenta un videoclub y que es el hombre que más sabe de cine al sur de la frontera de Arizona. Fate se descuelga del techo y se presenta; ha venido a cubrir el combate de boxeo para una revista de Harlem que se llama Amanecer Negro. Aparece el periodista Chucho Valdés -Fèlix Pons-, con chaqueta de cuero y porte chulesco. Presentan a Rosita Méndez, que ha sido novia de los dos y ahora sale con el propietario de una sala de bailes: «Rosita es así, está en su naturaleza. [...] Rosita también es un poco filósofa. [...] Y un poco puta» (Bolaño, 2007: s.p.).

Santa Teresa - le explican a Fate - es una ciudad que está «a mitad de camino entre un cementerio olvidado y un basurero» y tiene de todo: fábricas, maquiladoras, un cártel de cocaína, un flujo constante de trabajadores y emigrantes, pobreza, imaginación y burocracia (Bolaño, 2007: s.p.). Reconocemos en ese flujo constante de migrantes a la masa de seres humanos de que habla Bauman (2007: 45), «convertidos en superfluos por el triunfo del capitalismo global», residuos humanos que el planeta no es capaz de asimilar, aniquilar o desintoxicar. Por otra parte, el cementerio olvidado y el basurero, ese desierto voraz e indiferente, encajan con la definición de no lugares de 
Marc Augé — «espacios donde ni la identidad ni la relación ni la historia tienen verdadero sentido, donde la soledad se experimenta como exceso o vaciamiento de la individualidad» (Augé, 1998: 92)— que retoma Bauman (2003: 110) — los no lugares «desalientan cualquier idea de permanencia, imposibilitando la colonización o domesticación del espacio»- y que guardan parecido con lo que Jerzy Kociatkiewicz y Monika Kostera (1999: 43) denominan espacios vacíos, esto es, lugares a los que no se adscribe sentido alguno, inaccesibles debido a su invisibilidad; los espacios vacíos lo son en función del ojo que mira, del sujeto que mapea la ciudad, y por eso a los críticos de la primera parte les pasó por alto la tragedia del feminicidio en Santa Teresa.

Ferran Carvajal, caracterizado como Joven Guerra y con una copa en la mano, se desliza por el cubo, en una sutil coreografía, y se sitúa en el centro, mientras suena la canción Hold on de Tom Waits. Además de los ya enumerados, están en escena la periodista Guadalupe Roncal —interpretada por Chantal Aimée - y la joven Rosa Amalfitano, que conocemos de la segunda parte. Todos gesticulan y bailan como al ralentí, al ritmo de la música de Tom Waits. Después los ocho personajes miran en dirección a la platea, como si allí se desarrollara el combate de boxeo, y especulan sobre quiénes son los mejores boxeadores del país. Por detrás de ellos se desliza Omar Abdul —Joan Carreras, con guantes de boxeador y pañuelo rojo anudado en la cabeza-, el sparring del boxeador Merolino Fernández, dando golpes como a cámara lenta. Guadalupe Roncal le pide a Fate que la acompañe a la cárcel, donde tiene que hacerle una entrevista al principal sospechoso de las matanzas de Sonora: «Cuando se trabaja en los asesinatos de mujeres de Santa Teresa, una termina teniendo miedo a todo. Miedo a que te peguen. Miedo a la tortura» (Bolaño, 2007: s.p.).

De golpe, se oye ruido de multitudes. En la pantalla se proyectan imágenes confusas de un combate de boxeo. Todos callan menos Fate, quien retransmite el combate y anuncia que ha ganado Count Pickett. Después, al mismo tiempo que los personajes de carne y hueso interaccionan en el cubo, se proyectan sus imágenes grabadas arriba: así, mientras en el escenario los mexicanos invitan a Fate a una fiesta, en la pantalla se ve cómo todos entran en un local llamado El Rey del Taco y se sientan a una mesa que se va llenando de platos de comida. Suena la atronadora canción Gasolina de Daddy Yankee. Los actores bailan al ritmo del reggaetón. De golpe la música se minimiza, y las imágenes de arriba se ralentizan hasta devolver la filmación al tiempo real de los personajes sobre el escenario. Todos permanecen agachados menos Fate, que se levanta y habla al público de la razón por la que se ha quedado, su incipiente amor por Rosa Amalfitano, que también se levanta y se queda de pie, inmóvil.

Cambia la luz y Fate coge un micrófono para hablar de lo que ocurrió después de la cena, en las discotecas de Santa Teresa y más tarde en casa de Charly Cruz. Los actores se levantan y se pasan el micrófono. Sus rostros, 
filmados en tiempo real, se duplican en la pantalla de arriba. Hacen una relación de los hechos, como en un interrogatorio policial, y la cámara registra al que tiene el micrófono en cada momento. Mientras uno narra, otros escenifican acciones. En algún momento el Joven Guerra aparece colgado del techo, del revés. Chucho Flores taconea en el suelo y suena una música estridente. Todas las figuras de esta tercera parte se alimentan de violencia; sus extremados movimientos enfatizan lo asfixiante y claustrofóbico del reducido espacio en que interaccionan.

Añade Fate que en algún momento de la noche se unió a la comitiva un cuarto hombre, que no hablaba sino que sólo asentía y miraba el reloj. En escena, este hombre es interpretado por Joan Carreras, que lleva los mismos guantes de boxeador pero ahora tiene la cabeza cubierta por una máscara de luchador mexicano, la del Rayo de Jalisco. Cuenta Fate que en casa de Charly Cruz vieron una de las primeras películas de Robert Rodríguez, en que una prostituta vieja y pintarrajeada era penetrada por dos tipos hasta que la carne se le desprendía de los huesos y quedaba un esqueleto y una calavera que se reía. Los actores hacen gestos obscenos mientras el rostro de Rosita Méndez aparece en pantalla, como una premonición de que pronto será asesinada. También se proyecta la máscara que cubre el rostro de Carreras y que, distorsionada y multiplicada, deviene símbolo del mal, el peligro, la amenaza. La música se intensifica y los cuerpos de los actores se agitan convulsos. Fate le arrebata al extraño enmascarado una pistola y conduce afuera a Rosa Amalfitano. Suena la canción tradicional mexicana Las Mañanitas y desaparece la pantalla. Se van todos los personajes excepto Fate, Rosa y, entre ellos, Chucho Flores, encañonado por Fate. Siempre dentro del cubículo, ahora con un fondo azul que denota que han salido al exterior, Flores habla de estrellas y meteoritos.

Entra Óscar Amalfitano — «descalzo y despeinado, aparece caminando por el desierto en la misma luz irreal que antes Chucho Flores» (Bolaño, 2007: s.p.) - y les informa de que ha llamado la policía preguntando por ellos. Le pide a Fate que se lleve a Rosa lejos de Santa Teresa. En primer plano, en el proscenio, a mucha distancia del cubo - que queda atrás, azul, con los cuatro personajes, Fate, Rosa, Chucho Flores y Amalfitano, inmóviles como insectos atrapados en ámbar-, la periodista Guadalupe Roncal entrevista a Albert Kessler, ex agente del FBI interpretado por Manuel Carlos Lillo, que está apoyado en un muro, en el lateral izquierdo del escenario. Kessler, policía gringo jubilado, guionista y escritor de novela negra, asegura que «esta sociedad está fuera de la sociedad, todos, absolutamente todos son como los antiguos cristianos en el circo [...] lo mejor que podrían hacer todos es salir una noche al desierto y cruzar la frontera»(Bolaño, 2007: s.p. $)^{8}$. Fate, desde el

\footnotetext{
${ }^{8}$ El personaje de Albert Kessler, de mayor recorrido en la novela, es trasunto de Robert K. Ressler, exmiembro del FBI y asesor de películas de Hollywood, que acuñó el término de serial killer y lo popularizó, convirtiéndolo en emblema de la criminalidad contemporá-
} 
cubo, dictamina que en los asesinatos de Santa Teresa se esconde el secreto del mundo. Fin de la tercera parte.

Para contrarrestar el estatismo de la narración, se analiza la relación existente entre los personajes mencionados por Fate y encarnados por actores, y se escenifica a nivel de movimiento y acciones físicas. Así se construye un subtexto de interacciones, y se dota a la situación de complejidad, dinamismo y progresividad, que son para Sanchis Sinisterra (2003: 73) los tres parámetros de la acción dramática. Hay una superposición de lenguaje y metalenguaje, de presente y pasado. Los personajes evocados por el relato de Fate pasan a ser, en momentos determinados — como cuando se pasan el micrófono-, conarradores en la simulación de una voz omnisciente que hace de contrapunto a la narración en primera persona de Fate. Pero sobre todo interactúan a nivel gestual e incluso bailan coreografiados; casi se podría decir que funcionan como un coro. El cubo que Ordóñez ${ }^{9}$ asimila a un montacargas con el que descender a los infiernos deviene al final una suerte de jaula donde quedan encerrados los personajes, o un televisor con la imagen congelada.

En esta tercera parte domina la intermedialidad, así como la promiscuidad de elementos tecnológicos: micrófonos, cámaras y grabación en tiempo real: «En este tercer acto, con música ensordecedora, microfonía, espacio claustrofóbico y aparato gestual, se impone el Rigola más genuino de Julio César o Santa Joana dels escorxadors ${ }^{10}$. Hay la idea de un flujo simultáneo e ininterrumpido de imágenes o de emulsiones, todo entremezclado: lo real, fantasías, sueños, miedos, una película pornográfica amateur, un combate de boxeo, historias intercaladas. Los rostros en primer plano - los close-ups, y los talking heads, elementos muy expresivos de la televisión-, y las proyecciones en directo de planos detalle, se imbrican con una atmósfera cambiante en que intervienen juegos de luces, imágenes superpuestas y coreografías.

\section{LA PARTE DE LOS CRÍMENES}

Se levanta el telón y se ve un desierto con algunos matorrales resecos. Zumbido de insectos y perros que ladran. En primer término, un cuerpo de mujer ensangrentado sobre un plástico. Los tonos rosados del amanecer son lumínicamente impresos sobre una lona que envuelve tres cuartas partes del

nea, a partir de la película El silencio de los corderos - The Silence of the Lambs, dirigida por Jonathan Demme en 1991-, en la que trabajó como asesor (González Rodríguez, 2002: 14; Gras Miravet, 2012: 113).

${ }^{9}$ Ordóñez, Marcos... Vid. supra nota 1.

${ }^{10}$ Doria, Sergi (2007). «El secreto del mundo», ABC.es [en línea]. 29 de junio, s.p., <http:/ /www.abc.es/hemeroteca/historico-29-06-2007/abc/Espectaculos/el-secreto-delmundo_1633982664983.html> [ref. 13/07/16]. 
escenario. Señala Juan Carlos Olivares ${ }^{11}$ que la bolsa de plástico en la que se retuerce el cadáver halla su perfecta correlación en ese desierto envuelto asimismo en un cielo de plástico, bolsa forense colectiva que da cabida al conjunto de las asesinadas. Lalo Cura —interpretado por Ferran Carvajal- está arrodillado frente al cuerpo. Entran otros cuatro policías: Pedro Negrete -Manuel Carlos Lillo_- Juan de Dios Martínez — Julio Manrique_, Lino Rivera -Fèlix Pons - y Epifanio Galindo - Andreu Benito-. Los policías especulan sobre las causas de la muerte de la mujer. Juan de Dios dice, observándola, que es como si hubiera peleado quince rounds con Merolino Fernández. Pedro Negrete, al mando, habla por el móvil; sus secuaces disparan para que se callen unos perros que han empezado a ladrar. Lalo Cura la examina y afirma que se tomaron su tiempo para torturarla y matarla. Con absoluta indiferencia, los policías hablan de comida y del pozole original de los aztecas, uno de cuyos ingredientes, según Galindo, habría sido la carne humana. Salen a colación más denuncias de desapariciones, algunas de ellas vinculadas a la prostitución de lujo y al narcotráfico. La diputada Azucena Esquivel, que en la novela tiene cierta importancia por su interés en investigar el asesinato de su amiga Kelly Parker Rivera, es mencionada por Negrete como alguien a quien, junto a los periodistas, hay que acallar. También hablan del presunto asesino que sigue en prisión y se resiste a contar nada: se llama Klaus Haas y se sabe que nació en Prusia en 1955. Aparece en escena Haas - Joan Carreras, con tejanos, camiseta y gorra- y responde al interrogatorio de Galindo; en un momento dado, se deja llevar por visiones premonitorias acerca de un gigante que los va a matar a todos: «Un hombre muy grande, muy grande va a venir y te va a matar a ti y a todos. [...] Oigo sus pasos. El gigante ya está en camino. Es un gigante ensangrentado de la cabeza a los pies y ya se ha puesto en camino» (Bolaño, 2007: s.p.). Después Haas se acerca al primer término y desgrana un monólogo sobre su experiencia en la cárcel; denuncia el hecho de que los crímenes infligidos contra prostitutas y trabajadoras de las maquilas no se investigan o se imputan a quien no es culpable. Tras declarar su inocencia, Haas se va de la escena, por donde ha venido. Los policías están diseminados por el escenario. Epifanio dispara a los pies de Lalo Cura para provocarlo y reírse de él, y éste sale corriendo; desde detrás de la lona se le oye decir que ha descubierto a otra muerta. Los cinco policías abandonan la escena.

A continuación se proyecta la documentación real de las mujeres muertas en Ciudad Juárez. El periodista Sergio González Rodríguez, en Huesos del desierto (2002) —libro que para Bolaño (2004b: 215) deviene metáfora de México y del futuro de toda Latinoamérica, y se sitúa en la tradición apocalíptica que nos acerca al abismo que nos rodea-, proporciona el listado ofi-

\footnotetext{
${ }^{11}$ Olivares, Juan Carlos (2007). «Els fantasmes de Santa Teresa», Avui. 29 de junio, p. 50.
} 
cial de las muertas en Ciudad Juárez hasta el 23 de septiembre de 2002; si en la novela de Bolaño los nombres son inventados y llegan hasta diciembre de 1997, en el montaje de Rigola se opta por incluir la lista real ampliada, desde 1993 hasta 2003, según el informe de la Comisión Nacional de Derechos Humanos de México, presentado en noviembre de 2003.

La mujer ensangrentada, que no es sino Rosita Méndez, se revuelve en el suelo, como tratando de huir de su torturador. Con un micrófono amplifica sus gritos, sus gemidos, su miedo. Los cinco hombres van depositando cruces rosas en el espacio y convierten el desierto en un camposanto. Suena el segundo movimiento de la Séptima Sinfonía (Opus 92) de Beethoven; en este sentido señala López García (2008: 215) que la marcha fúnebre es una respuesta del orden cultural ante el horror y la muerte. Al final de la proyección de nombres, la mujer emite unos últimos alaridos, se convulsiona y finalmente se aquieta. Vuelven a salir los policías y cuentan chistes alrededor del cadáver. Chistes horriblemente machistas que no arrancan ni una carcajada al público.

En la dramatización de Ley y Rigola, esta cuarta parte es la menos fiel al texto de Bolaño. Se obvian las distintas líneas de investigación que se suceden: la de Juan de Dios Martínez y la de otros judiciales como Lalo Cura - cuya genealogía es largamente referida- y el joven Epifanio Galindo, dotado de talento y agallas. Aparecen estos personajes, pero no el detalle de sus pesquisas; se dejan de lado las explicaciones e hipótesis barajadas en torno a la autoría de los crímenes, como la existencia de un asesino en serie o la filmación de snuff movies. Esta parte la escribió Bolaño gracias a los datos que le suministró el periodista Sergio González Rodríguez: informaciones relevantes del proceso de investigación de las muertes, detalles como armas, calibres y vehículos de los narcotraficantes, así como transcripciones de actas judiciales. Como señala Dunia Gras Miravet (2012: 110), Huesos en el desierto puede considerarse un hipotexto, aunque no el único, de $2666^{12}$.

Así, el formato del informe policial - sistema rutinario de registro de los crímenes - y el reportaje de la crónica roja parodiados en la retórica de Bola$\tilde{\text { ño }}{ }^{13}$ no se recogen en esta cuarta parte de la dramatización. También se han

${ }^{12}$ Gras Miravet (2012) ha documentado el tipo de relación transtextual, dialógica, que se establece entre Huesos del desierto de Sergio González y 2666 de Roberto Bolaño, para después valorar ese otro diálogo intermediático entre la novela del autor chileno y la transposición teatral realizada por Rigola. Resulta particularmente fructífero y revelador el cotejo entre el capítulo «La vida inconclusa» de Sergio González y «La parte de los crímenes» de Roberto Bolaño. Ambos muestran un «paralelismo estructural, la enumeración pormenorizada de las víctimas, aunque en el primer caso el orden temporal corra invertido» (Gras Miravet, 2012: 117).

${ }^{13}$ En la cuarta parte de la novela, Bolaño adopta un lenguaje forense y un ritmo propio del sumario policial, a través de una cadencia monocorde, trabajada sobre la repetición - por la acumulación de nombres y crímenes- con principios de variación. Señala Carlos 
suprimido algunos personajes relevantes de la novela, como la vidente Florita Almada y, sobre todo, el periodista al que acabamos de aludir, Sergio González Rodríguez, autor de Huesos en el desierto y, por lo tanto, personaje procedente del mundo real, utilizado para reforzar el efecto de realidad del relato pero tratado de tal manera en la narración que llega a adquirir una personalidad propia dentro de la ficción (Gras Miravet, 2012: 115).

Rigola enfatiza en la brecha abierta entre el lenguaje de pretensión cientificista, con sus detalles morbosos, y la vivencia descarnada de una víctima. Esta parte fue concebida por Rigola como una suerte de oratorio y también como una instalación, con la lista de atroces muertes de fondo, ilustrando la magnitud del feminicidio. Las más de trescientas páginas de la novela son condensadas en poco menos de treinta minutos de puesta en escena, en una eficaz síntesis y una funcional, hermenéuticamente diáfana, transposición escénica del crudo relato de los crímenes. Si la violencia se concibe como una enfermedad que se mantiene escondida — «las mujeres de Santa Teresa son enterradas rápidamente en fosas comunes que las devuelven a su anonimato» (Bolognese, 2009: 143) —, los detalles de los actos violentos y de las víctimas, en la novela de Bolaño, son un modo de dar una identidad a esas mujeres y de crear el horror como forma a través del principio de colección (Walker, 2013: 174). Rigola, a pesar de prescindir de la acumulación de datos, halla la manera de traducir en escena el horror a través del dolor individual, la agonía de una víctima. Logra, así, eso que Angélica Liddell llama «recuperar la intimidad contra la fosa común», «reafirmar al individuo» y «oponerse a los horrores anónimos y colectivos, al horror del exterminio» (Liddell, 2014: 23).

La identificación del espectador con lo que sucede en escena es total y no hay posibilidad de mantener a raya la emoción — a diferencia de lo que ocurría en la tercera parte, construida a partir de múltiples recursos de distanciamiento-; así, se hace a los espectadores «partícipes de la cadencia asesina con la que se construye la historia» (Rodríguez Serrano, 2010: s.p.). Los chistes machistas de los hombres, contrapunto anticlimático del crudo trasvase emocional inmediatamente anterior, no hace sino evidenciar la impunidad de los crímenes y la corrupción policial. Señala Edmundo Paz Soldán (2008: 21) que «la imposibilidad de escapar de los prejuicios sexistas y racistas tiene un correlato directo con la imposibilidad de resolver los crímenes». Ello enlaza con la afirmación del periodista Sergio González Rodríguez (2002: 13) de que estas

\footnotetext{
Walker (2013: 157) que «Quizá la antología sea un modo en el que Bolaño presenta el horror como forma», modo narrativo que evita la abyección estetizante y que se halla prefigurado en obras anteriores de Bolaño. La serie de cadáveres de Santa Teresa permite entrever el vínculo formal con la antología y el principio de colección — «El principio de colección [...] una de sus estrategias de composición del horror» (Walker, 2013: 174)— que primaba ya en La literatura nazi en América (1996) y en el episodio de la muestra de fotos en Estrella distante (1996).
} 
muertes se explican, en gran medida, por flaquezas culturales endémicas — «La sobrepoblación, la penuria urbana, la violencia externa o intrafamiliar, las inercias de género [...] transformaban lo cotidiano en una pesadilla singular»—, pero también se inscriben dentro de un fenómeno mucho más amplio y de alcance mundial, en la «era de una zona fronteriza global y de la delincuencia globalizada» (Bauman, 2005: 98). La brutalidad y la impunidad que allí imperan no hacen sino traslucir dos hechos: «la inadvertencia o amnesia global ante un fenómeno extremo de signo anárquico; y el impulso de normalizar la barbarie en las sociedades contemporáneas» (González Rodríguez, 2002: 159).

\section{LA PARTE DE ARCHIMBOLDI}

La quinta parte nos devuelve a un espacio prácticamente vacío, donde destacan una cinta de correr y, detrás de ella, una pantalla. La señora Bubis -interpretada por Alícia Pérez, con traje chaqueta negro y collar de perlas-, sentada e iluminada en medio de una gran oscuridad, es la voz que principia la narración de la vida de Hans Reiter/Archimboldi: «Su madre era tuerta. Su padre era cojo. El pequeño Hans no parecía un niño sino un alga y lo que le gustaba era el fondo del mar [...] se movía por la superficie de la tierra como un buzo primerizo por el fondo del mar» (Bolaño, 2007: s.p.). Se perfila la figura de un joven Reiter - Joan Carreras, con pantalón largo y el torso desnudo- que entra por el lateral izquierdo y se sitúa ante la pantalla, en la que se proyecta una imagen del fondo marino. Se nos cuenta que la primera persona por la que se interesó Reiter fue su hermana Lotte, diez años menor - la interpreta Cristina Brondo, inmóvil junto a Reiter delante de la pantalla azul- y que su primer trabajo, a los trece años, consistió en sacar el polvo de una inmensa biblioteca, en la casa de campo del barón Von Zumpe. Interviene ahora otro personaje, Hugo Halder —Fèlix Pons, caracterizado como un joven aristócrata alemán-, sobrino del barón, que inició a Reiter en la literatura alemana. Cuando en 1936 el barón Von Zumpe cerró la casa de campo, Reiter se dirigió a la casa de Halder en Berlín, y éste le consiguió un trabajo de vigilante nocturno en una fábrica de fusiles.

Se turnan los tres — Hugo, la señora Bubis y Reiter - para hacer avanzar la narración. Cuando se alude a las noches de diversión de Reiter y Halder en los cabarets de Berlín, se proyectan imágenes de vedettes del género. En 1939 Reiter fue llamado a filas. Un Soldado Alemán —interpretado por Julio Manrique- describe algunos episodios de la guerra: «Cuando partimos pensé que Reiter moriría. Era como ver a una jirafa en un pelotón de lobos, coyotes y hienas. [...] Lejos de servir como blanco fácil, Reiter había asustado de alguna manera a los defensores» (Bolaño, 2007: s.p.). Se proyectan en la pantalla imágenes en blanco y negro del ejército, en alternancia con las imágenes del 
fondo marino. Polonia, Hungría, Rumanía son los destinos que se suceden en la vida militar de Reiter. Mientras se narran algunos hechos de guerra, un oficial de las SS -interpretado por Ferran Carvajal, unos pasos por detrás de la figura inmóvil de Reiter- desfila con paso marcial por delante de la pantalla que emulsiona imágenes de guerra, tanques, soldados y nieve hollada.

Después se narra cómo, en un castillo rumano donde se había instalado con la tropa —en la pantalla, primeros planos de piedras del muro de un castilloReiter reencontró a la baronesa Von Zumpe e incluso, una noche, la descubrió en pleno lance sexual con el general Entrescu: la actriz Alícia Pérez se quita la chaqueta de señora Bubis para encarnar a la baronesa, y se queda con los pechos al descubierto durante unos instantes para narrar cómo ésta se mordía la mano para no gritar de placer. El Soldado se sitúa junto a la cinta de correr, pero ni él ni Reiter se mueven. A la mañana siguiente —cuentan- los soldados abandonaron el castillo.

En junio de 1941 empezó el ataque a la Unión Soviética. Reiter —un valiente o un suicida - expuso su vida en muchas ocasiones y siempre se ofrecía voluntario para las empresas más arriesgadas; fue herido y después volvió al combate, en frentes sucesivos. Cuando relatan sus distintas batallas, Reiter y el Soldado caminan sobre la cinta de correr; no escenifican lo narrado sino que narran los hechos mientras caminan. Más adelante será el general de las SS quien se suba a la cinta; en un momento dado, extenderá los brazos y torcerá la cabeza para representar la crucifixión del general Entrescu. De este modo el montaje de Rigola refleja la idea de Archimboldi de que «la historia, que es una puta sencilla, no tiene momentos determinantes sino que es una proliferación de instantes, de brevedades que compiten entre sí en monstruosidad» (Bolaño, 2004a: 993), haciéndose eco, por parte, de la tesis baumaniana de la disolución del tiempo en la sociedad globalizada: «¿Será, tal vez, que tras haber aniquilado el espacio como valor, el tiempo se ha suicidado? ¿No habrá sido el espacio simplemente la primera víctima de la frenética carrera del tiempo hacia su propia aniquilación?»(Bauman, 2003: 128).

Se ilumina el personaje de Lotte en el centro del escenario, con un vestido claro floreado, de niña, reproduciendo oralmente las palabras escritas en las cartas que le mandaba a su hermano: «Tú eres un gigante. Tus pasos resuenan en el bosque. Los pájaros del bosque oyen el sonido de tus pisadas y dejan de cantar. [...] Los jóvenes de las Juventudes Hitlerianas te oyen y acuden a esperarte a la entrada del pueblo. Todo es alegría» (Bolaño, 2007: s.p.). En estas palabras reconocemos las que Klaus Haas — sabremos que es hijo de Lotte y sobrino de Reiter- pronunció en la cuarta parte, durante el interrogatorio con la policía de Santa Teresa.

En un campo de prisioneros en las afueras de Ansbach, Reiter conoció a Leo Sammer -interpretado por Manuel Carlos Lillo, cubierto con una manta-, a quien habían encomendado la misión de deshacerse de quinientos prisioneros judíos y que fue estrangulado una noche por no haber completado 
la tarea. En la pantalla, el paisaje nevado es sustituido por imágenes de prisioneros en campos de concentración, trenes y cadáveres hacinados. La proyección de imágenes de archivo — mostración de lo inefable — recogidas por las tropas aliadas durante la liberación de los campos de concentración y exterminio de la Alemania nazi lleva implícita una comparación entre las víctimas de las cámaras de gas y las mujeres asesinadas en Ciudad Juárez. Rodríguez Serrano (2010: s.p.) resalta la capacidad de Rigola para «dar voz y presencia a las víctimas. Pero también para unificarlas e igualarlas sin caer en los tópicos del sistema ideológico que las genera». El director es muy dado a este tipo de síntesis o asimilaciones; así, por poner dos ejemplos conocidos, en el montaje de Santa Juana de los Mataderos (2004) fusionaba la imagen de la Juana de Arco de Carl Theodor Dreyer con los logotipos de las marcas más representativas del capitalismo neoliberal, y en Ubú Rey (2002) cruzaba el personaje creado por Jarry con elementos característicos de dictadores como Hitler, Franco o Trujillo, pero también de líderes políticos actuales como George Bush o José María Aznar.

Después se nos cuenta que, tras salir del campo, Reiter conoció a Ingeborg, hija de un miembro del partido que se había suicidado; con ella —interpretada por Chantal Aimée, en combinación blanca y con trenzas rubias- Reiter inició un duradero romance. A raíz de las palabras de una adivina — «Te recomiendo que cambies de nombre. Es necesario que no vuelvas al lugar del crimen. Es necesario que rompas la cadena» (Bolaño, 2007: s.p.)—, Reiter cambia de nombre y de vida para iniciar una larga y brillante, aunque soterrada, carrera como escritor.

Al contar la historia del encuentro de Reiter con el editor, se sustituyen en pantalla las imágenes acuáticas por un primerísimo plano de las teclas de una antigua máquina de escribir. Jacob Bubis - interpretado por Andreu Benito, con chaleco y pajarita, y un puro en la mano- publicará los libros de Reiter, que será conocido desde ese momento por su pseudónimo artístico, Benno von Archimboldi. El editor está casado con una refugiada aria de buena familia que ahora responde al nombre de señora Bubis pero cuya antigua identidad es bien conocida por Reiter/Archimboldi: se trata de la baronesa Von Zumpe; ella también lo reconoce, como un antiguo empleado reencontrado en el castillo de los Cárpatos. Se superponen diferentes tiempos. Ahora Reiter está en el centro de la escena, entre el señor y la señora Bubis; Ingeborg está sobre la cinta, inmóvil. Cuando se narra que él y la señora Bubis hicieron el amor en un hotel de Hamburgo, tres noches seguidas, la baronesa/señora Bubis se abre la chaqueta y muestra los pechos.

Cuentan que Ingeborg enfermó de tuberculosis y la pareja se fue a reposar a una aldea de montaña cerca de la frontera austriaca; de allí, por deseo expreso de Ingeborg, viajaron a Austria, Suiza e Italia. La proyección del firmamento acompaña el parlamento de Ingeborg sobre las estrellas y su luz que procede del pasado. Archimboldi y su mujer andan sobre la cinta para contar 
sus viajes, narración rubricada con la emulsión en pantalla de imágenes de montañas, bosques y cielos. El señor Bubis explica que Archimboldi desapareció, y lo último que se supo fue que Ingeborg había muerto ahogada, mar adentro, en un pueblo de Italia.

El señor Bubis muere, y el actor Andreu Benito abandona el escenario. La señora Bubis y Archimboldi se turnan para hablar: ella en el centro del escenario, de pie y con los brazos cruzados, y él caminando en la cinta. La proyección de islotes en mitad de un mar muy azul ilustra el relato de su vivencia en varias islas griegas. Emerge del pasado la hermana de Archimboldi, Lotte Reiter. Ésta, iluminada en el centro del escenario, explica cómo reconoció a su hermano en el autor de un libro comprado por casualidad en el aeropuerto — camino de Santa Teresa, donde su hijo, Klaus Haas, estaba acusado de haber matado a varias mujeres-. Los hermanos se reencontraron en Alemania y ella le pidió que se encargara de todo. Archimboldi sigue caminando en la cinta. Al fondo, Ferran Carvajal danza con el torso desnudo, como un doble de Archimboldi. Con la proyección de un parque verde al fondo, la señora Bubis cuenta una última historia a propósito del momento inmediatamente anterior al viaje de Archimboldi a México: en una terraza, un caballero, Alexander fürst Pückler - Víctor $\mathrm{Pi}$, con traje de franela y sombrero-, se dirige a Archimboldi para hablarle de un antepasado suyo, viajero y escritor prolífico que al final sería recordado por una combinación de helados que inventó, el fürst Pückler. Esta última narración viene a hablar de la futilidad de todo intento por transcender, así como de los caprichos de la posteridad.

En la última intervención de la obra, la señora Bubis dice que Archimboldi, que entonces contaba ochenta años, salió del parque y a la mañana siguiente se marchó a México. Estas últimas palabras son rubricadas con la proyección de una imagen gigante de Archimboldi en la pantalla, grabación en tiempo real del Archimboldi que camina sobre la cinta; su imagen proyectada se va multiplicando a medida que el actor acelera el ritmo. En escena están la señora Bubis y el bailarín, casi borrados en la oscuridad, y Alexander fürst Pückler, iluminado como el lúcido testigo del desvanecimiento de Reiter o Archimboldi, que corre en pos de su destino, huyendo de sí mismo hacia el punto de fuga. Esta imagen final del espectáculo contrasta con el final de la novela, que impone la imagen del desierto como el fin de la civilización.

\section{CONCLUSIONES}

La adaptación de Pablo Ley y Àlex Rigola busca trasladar la fábula sin traicionar el texto, preservando la potencia y el empuje de la prosa de Roberto Bolaño en toda su complejidad y fragmentariedad, traduciendo al lenguaje escénico los mecanismos narrativos. Es de notar la extrema dificultad de dramatizar una novela cuya estructura discontinua y llena de huecos se cierne en 
torno a la idea de viaje o de búsqueda. En la dramatización se minimiza la propensión de Bolaño al catálogo y la taxonomía, y se elimina una gran cantidad de personajes secundarios; si no, se produciría dispersión y se desactivaría el sentido, por reiterativo y demasiado diseminado. Así, se han suprimido personajes episódicos que podrían lastrar el ritmo del espectáculo, como Elvira Campos y su inventario de fobias, o el judío Ansky y su diario encontrado, entre muchísimos otros. La supresión del personaje de Sergio González, el periodista cuyo libro Huesos en el desierto funciona como hipotexto de la novela 2666, debe entenderse no sólo por motivos de economía diegética sino también como modo de mitigar el referente local de Ciudad Juárez y promover un alcance global de la violencia. Además de los omitidos, hay que tener en cuenta a los personajes ausentes: los puramente referenciales, los extraescénicos — los boxeadores de la tercera parte- y los incorpóreos — la voz del padre de Amalfitano-. Por otra parte, hay personajes muertos - la esposa de Amalfitano-, desaparecidos —Archimboldi- o incluso imaginarios - la emulsión onírica de Boris Yeltsin — que se encarnan en el cuerpo de los actores.

El discurso se vuelve hacia el pasado, que es revisado con prolijidad y tendencia digresiva, si bien también hace presagiar el futuro, el mal definitivo o el cementerio del año 2666. La temporalidad conserva, en lo esencial, el orden secuencial de los acontecimientos, tal como son narrados — la novela está llena de relatos retrospectivos que continuamente hacen a la instancia narrativa volver atrás-. Continuamente los personajes explican o reviven hechos pasados, si bien en la cuarta parte se apela directamente a la emoción del público. Hay también sucesos que no llegan a ocurrir en escena pero que se apuntan como de ocurrencia inminente; así, la llegada del gigante ciego que invoca Haas, o las premoniciones funestas del hamletiano fantasma del padre de Amalfitano, la alerta de que las cosas están al rojo vivo. En la quinta parte de la novela se nos dice que Archimboldi, una noche, «se entretuvo en pensar en un tiempo de dos velocidades, uno era muy lento y las personas y los objetos se movían en este tiempo de forma casi imperceptible, el otro era muy rápido y todo, hasta las cosas inertes, centelleaban de velocidad» (Bolaño, 2004a: 1001). Este juego con el tiempo y con el tempo tiene una traducción escénica en la danza que Ferran Carvajal realiza al fondo, como al ralentí, situándose en el punto de fuga, como la danza no puede por menos de hacer ${ }^{14}$.

Cada parte cuenta con un espacio marco, una escenografía que deviene contenedor o receptáculo de la acción dramática, «una especie de taller escénico en el que se condensan procedimientos anteriores y se experimentan otros caminos menos explorados por Rigola» (López García, 2008: 211). En la tercera y quinta partes, los marcos escenográficos son ajenos a lo descrito por el

${ }^{14}$ Marcia Siegel (1972: 1) señala que la danza existe en un punto de fuga perpetuo. Ningún otro arte es tan difícil de capturar y retener. 
texto: funcionan por relación metafórica; en las otras tres, hay elementos que operan metonímicamente para representar alguno de los espacios evocados en la novela: sala de conferencias, jardín de Amalfitano y desierto de Sonora respectivamente.

La importancia de lo onírico en la novela se mantiene en el espectáculo, a la manera de subrayado atmosférico y psicológico y de alerta ominosa. A menudo se concede a lo soñado la misma importancia que a lo vivido; ello tiene que ver con un «sistema de relaciones fundado en la igualdad ontológica de las experiencias [...] resultado conjunto de una poética que define toda existencia como existencia narrativa», en palabras de Pablo Blas Corro Pemjean (2005: 127). Señala Arturo García Ramos (2008: 126) que la novela 2666 «tiene una apariencia de obra inacabada, de sueño interrumpido. Pero todo en ella apunta a que hay un narrador no declarado [...]. Su voz está transida de ficción, es decir, de irrealidad». Como si todo fuera una deliberada suplantación ficcional de la realidad y en cualquier momento pudiera arrogarse la autoría del texto Arturo Belano — «Esta vez el detective está fuera del libro, narrándolo», apunta Juan Villoro (2008: 87) — o el mismo Benno von Archimboldi. En la versión de Ley y Rigola predomina la acción de narrar, pero se rehúye deliberadamente la omnisciencia y se otorga a diversos personajes el estatuto híbrido de personajes teatrales y de narradores múltiples y alternados. Los diversos narradores, en escena y encarnados por actores, son también personajes y, por ello, están en mayor o menor grado implicados o comprometidos con la historia que cuentan, y se ven afectados y modificados por ella; esto es particularmente cierto en el caso de Amalfitano y Fate, que narran en primera persona. Como señala el actor Joan Carreras, en este espectáculo los intérpretes funcionan como transmisores de la historia, y de la palabra de Bolaño (Gomila, 2007: 36). A nivel de recepción, domina el esquema del receptor incluido: el público es el destinatario del relato y asiste a la rememoración de una historia, si bien se intercalan escenas eminentemente dramáticas.

En la puesta en escena de Rigola se obvia toda referencia a la pintura, pero ésta constituye para Bolaño una vía de exploración y reflexión estética; en las páginas de la quinta parte consagradas al cuaderno del escritor ficticio Boris Ansky (Bolaño, 2004a: 883-929) —-suprimidas en la adaptación teatral por motivos de economía narrativa-, se mencionan Gustave Courbet y sobre todo Giuseppe Arcimboldo, de quien toma Reiter su apodo o alias y cuya técnica permite entender, descubrir o redimensionar la estructura de 2666 , novela minada de catálisis y digresiones en que la parte funciona como el todo. Y, si la importancia de la pintura no se refleja en la dramatización, lo mismo ocurre con el cine: las citas fílmicas que aparecen en la novela —así, la película de terror Ringu, del japonés Hideo Nakata (1998), o el film de cine negro The Limey, del estadounidense Steven Soderbergh (1999), que referencia Corro Pemjean (2005: 124) — no se trasladan al teatro, ni bajo la forma de proyecciones ni en la narración de los actores en escena. Sí que se reflejan, referi- 
das en el nivel narrativo, las relaciones con el cine negro - a través del personaje de Albert Kessler- e infragéneros como el porno, el snuff y la serie B policial. Aunque se omiten las referencias fílmicas y otros dispositivos visuales, el contenido audiovisual es presente en escena a través de imágenes proyectadas y filmaciones: una entrevista, una fiesta mexicana, proyecciones del fondo marino, imágenes de archivo de los campos de concentración, etc.

En la puesta en escena de 2666 se potencia la cualidad transgenérica, que responde formalmente al problema de indeterminación, «la labilidad genérica con que la realidad reclama ser tratada en la actualidad» (Echevarría, 2008: 437), y ello está en consonancia con la trayectoria de Àlex Rigola. En 2666 hallamos algunos de los elementos recurrentes en sus puestas en escena, como son pinceladas de danza, filmaciones y, sobre todo, música, ingrediente básico e irrenunciable de su teatro. Así, en Ricardo 3. ${ }^{\circ}$ (2005) había actuaciones en directo; en Glengarry Glen Rose (2003), un disc-jockey pinchaba música electrónica en escena, y Rock'n'roll (2008), además de abordar temáticamente la Primavera de Praga, recuperaba y homenajeaba la figura de Syd Barrett, entre temas de Pink Floyd, Plastic People of the Universe y The Rolling Stones. Las grabaciones en tiempo real y las coreografías se hallan, entre muchos de sus montajes, en Santa Juana de los Mataderos (2004); en Nixon-Frost (2009) se hizo un uso abundante de las filmaciones y la duplicación de los actores en pantalla. La influencia del cine de Lynch era patente en Mcbth (2012), y el género del western se hallaba presente, en clave paródica y gamberra, en The End (2011), el narcomex-spaghetti-western teatral con que Rigola cerró su etapa como director del Teatre Lliure. Usados mayormente como mecanismos de distanciamiento, estos elementos contribuyen al espesor significativo de la adaptación. Pero también la economía de actores y la sobriedad escenográfica de la primera y quinta partes de 2666 tienen precedentes y continuidad en la trayectoria de Rigola como director; así, en Julio César (2002) el espacio vacío y el esmoquin informal que vestían los intérpretes sugería una ubicación temporal indeterminada, y Coriolano (2012) exhibía un formato próximo a la lectura dramatizada. Hemos señalado ya la tendencia de Rigola a interponer entre el texto de partida y su realización escénica una proliferación de símbolos que permiten hacer analogías y extrapolaciones, así como asimilar o equiparar fenómenos sociopolíticos de tiempos y espacios muy diversos; esto lo ha trabajado a conciencia con los textos de Shakespeare, desde Titus Andrònic hasta Mcbth y Coriolano. Su gusto por la performance y la instalación artística se hacen patentes en la cuarta parte de 2666, en que una sola mujer agonizante nos hace oír su dolor durante ocho minutos, compendiando en su experiencia el centenar de muertes violentas que contiene la novela; Rigola crea así un efecto de gran condensación dramática y transforma la información en horror.

Señala Gras Miravet (2012: 124) que gracias al formato teatral se subraya de modo más evidente que en la novela el paralelismo entre el genocidio judío y el feminicidio en la frontera entre México y EE. UU. De este modo la 
escena acaba deviniendo un cementerio: a los nombres de las más de trescientas asesinadas en Ciudad Juárez que se proyectan en pantalla hay que sumarles todos los muertos anónimos de las guerras europeas del siglo XX; más de cerca, el cadáver ensangrentado de Rosita Méndez revive sus últimos minutos de agonía, y personajes que ya murieron son convocados por el recuerdo de otros y eventualmente corporeizados. En este sentido, señala Rodríguez Serrano (2010: s.p.) que «2666 es un discurso que se articula precisamente en el corazón del cadáver».

La realidad, esquiva e inaprehensible, sólo se puede interpretar de un modo vacilante e imperfecto, y es abordada desde múltiples ángulos, enfoques y perspectivas —desde los múltiples códigos expresivos de la puesta en escena—, con la certeza de que falta siempre una pieza que complete el sentido, el dibujo, el mapa. Santa Teresa, trasunto de Ciudad Juárez y punto donde convergen personajes procedentes de distintos países y latitudes, deviene «tierra baldía del capitalismo globalizado» (Elmore, 2008: 261) y, en palabras del propio Rigola, «señala la brutalidad del capitalismo: la frontera con Estados Unidos, los que quieren pasar al otro lado, las maquiladoras, la economía sucia de la droga y la prostitución» ${ }^{15}$. Esta ciudad infierno donde reina la barbarie es un no lugar o tierra de nadie en que el crimen parece ser la ley, y por donde pulula una multitud de excluidos y parias, los residuos humanos de que habla Bauman y que, por su absoluta indefensión y falta de derechos, son víctimas potenciales de la injusticia y la brutalidad. Pero, más allá de Santa Teresa o Ciudad Juárez, cabe tener en cuenta el alcance global — globalizado— de esta violencia de signo anárquico. Ya dijo Bolaño (2004b: 20) que «el crimen parece ser el símbolo del siglo $\mathrm{XX}$ ». El frío viento de la fatalidad azota la escena, y los personajes, en la intemperie moral, se desvanecen en el desierto del mal y la desmemoria.

\section{BIBLIOGRAFÍA CITADA}

Augé, Marc (1996). El sentido de los otros. Actualidad de la antropología. Barcelona: Ediciones Paidós Ibérica.

Augé, Marc (1998). Los no lugares. Espacios del anonimato. Barcelona: Editorial Gedisa.

Bauman, Zygmunt (2003). Modernidad líquida. México D. F.: Fondo de Cultura Económica.

Bauman, Zygmunt (2005). Vidas desperdiciadas. La modernidad y sus parias. Barcelona: Ediciones Paidós Ibérica.

Bauman, Zygmunt (2007). Tiempos líquidos. Vivir en una época de incertidumbre. Barcelona: Tusquets Editores.

Bauman, Zygmunt (2009). Amor líquido. Acerca de la fragilidad de los vínculos humanos. Madrid: Fondo de Cultura Económica.

Bolaño, Roberto (1999). Amuleto. Barcelona: Anagrama.

Bolaño, Roberto (2004a). 2666. Barcelona: Anagrama.

Bolaño, Roberto (2004b). Entre paréntesis. Barcelona: Anagrama.

\footnotetext{
${ }^{15}$ Larios Ruiz... Vid. supra nota 3.
} 
Bolaño, Roberto (2007). 2666. Barcelona: Fundació Teatre Lliure - Teatre públic de Barcelona. Bolognese, Chiara (2009). Pistas de un naufragio. Cartografía de Roberto Bolaño. Santiago de Chile: Editorial Margen.

Corro Pemjean, Pablo Blas (2005). «Dispositivos visuales en los relatos de Roberto Bolaño», Aisthesis. 38, pp. 121-133.

Echevarría, Ignacio (2008). «Bolaño extraterritorial», en Edmundo Paz Soldán y Gustavo Faverón Patriau (ed.), Bolaño salvaje. Barcelona: Candaya, pp. 431-445.

Elmore, Peter (2008). «2666: la autoría en el tiempo del límite», en Celina Manzoni (ed.), Roberto Bolaño: la escritura como tauromaquia. Buenos Aires: Corregidor, pp. 259-292.

García Ramos, Arturo (2008). «Última hora de la novela: 2666 de Roberto Bolaño», Anales de Literatura Hispanoamericana. 37, pp. 107-129.

Gomila, Andreu (2007). «Entrevista: Joan Carreras», Avui. 5 de noviembre, p. 36.

González Rodríguez, Sergio (2002). Huesos en el desierto. Barcelona: Editorial Anagrama.

Gras Miravet, Dunia (2012). «De Sergio González a Àlex Rigola, pasando por Roberto Bolaño: cortesías y transtextualidades. A propósito de 2666», en Augusta López Bernasocchi y José Manuel López de Abiada (ed.), Roberto Bolaño, estrella cercana. Ensayos sobre su obra. Madrid: Editorial Verbum, pp. 107-125.

Kociatkiewicz, Jerzy y Monika Kostera (1999). «The anthropology of empty space», Qualitative sociology. 22, 1, pp. 37-50.

Ley, Pablo (2007). «2666-Una aproximació a la posada en escena», en Roberto Bolaño, 2666. Barcelona: Fundació Teatre Lliure - Teatre públic de Barcelona.

Liddell, Angélica (2014). El sacrificio como acto poético. Madrid: Continta me tienes.

López García, José Ramón (2008). «El mal en escena: 2666, de Roberto Bolaño», en José Romera Castillo (ed.), Teatro, novela y cine en los inicios del siglo XXI. Madrid: Visor Libros, pp. 203-222.

Manzoni, Celina (2002). «Narrar lo inefable. El juego del doble y los desplazamientos en Estrella distante», en Celina Manzoni (ed.), Roberto Bolaño: la escritura como tauromaquia. Buenos Aires: Corregidor, pp. 39-50.

Paz Soldán, Edmundo (2008). «Roberto Bolaño: Literatura y apocalipsis», en Edmundo Paz Soldán y Gustavo Faverón Patriau (ed.), Bolaño salvaje. Barcelona: Candaya, pp. 11-30.

Prieto Nadal, Ana (2014). «El policía de las ratas a escena», Pasavento. Revista de Estudios Hispánicos [en línea]. II, 2, pp. 449-461, disponible en <http://www.pasavento.com/ pdf/04_12_prieto.pdf > [ref. de 13/07/16]

Rodríguez Serrano, Aarón (2010). «Escena/cementerio: sobre 2666 (de Roberto Bolaño) en la versión teatral de Àlex Rigola» [en línea], disponible en: <http://www.perio.unlp.edu.ar/ ojs/index.php/question/article/viewFile/544/462> [ref. de 13/7/16].

Sanchis Sinisterra, José (2003). Dramaturgia de textos narrativos. Ciudad Real: Naque.

Siegel, Marcia B. (1972). At the Vanishing Point: A Critic Looks at Dance. New York: Saturday Review Press.

Villoro, Juan (2008). «La batalla futura», en Edmundo Paz Soldán y Gustavo Faverón Patriau (ed.), Bolaño salvaje. Barcelona: Candaya, pp. 73-89.

Volpi, Jorge (2008). «Bolaño, epidemia», en Edmundo Paz Soldán y Gustavo Faverón Patriau (ed.), Bolaño salvaje. Barcelona: Candaya, pp. 191-207.

Walker, Carlos (2013). «Horror y colección en Roberto Bolaño», Kamchatka. 1, pp. 155-177.

Fecha de recepción: 28 de abril de 2014.

Fecha de aceptación: 14 de noviembre de 2014. 